\title{
Release of endothelins and platelet-activating factor by a rat pleural mesothelial cell line
}

\author{
I. Kimura, Y. Sakamoto, M. Shibasaki, Y. Kobayashi, H. Matsuo
}

\begin{abstract}
Release of endothelins and platelet-activating factor by a rat pleural mesothelial cell line. I. Kimura, Y. Sakamoto, M. Shibasaki, Y. Kobayashi, H. Matsuo. (C)ERS Journals Ltd 2000. ABSTRACT: Thrombin is a multifunctional serine protease. It is generated in inflammatory processes and induces the proliferation and chemotaxis of a variety of cells including mesothelial cells (MTCs). MTCs are epithelial cells derived from the mesoderm, as are the vascular endothelial cells. Since thrombin acts on endothelial cells to produce platelet-activating factor (PAF) and endothelin (ET)-1, it was hypothesized that MTCs also produce PAF and ET via the action of thrombin.

Rat pleural MTC (RMTC, 4/4 R.M.-4) monolayers were cultural in tissue culture dishes for various periods. The supernatants were fractionated by means of highperformance liquid chromatography to determine the ET isoforms and PAF species present. Immunoreactive ET was measured using an enzyme-linked immunosorbent assay, and PAF was measured by means of a bioassay using a platelet aggregometer.

ET-1, ET-2 and ET-3 were detected in RMTC-conditioned medium, and the predominant isoforms were ET-1 and ET-2. RMTCs mainly released C16:0 PAF into the supernatant. Immunoreactive ET and PAF were released via the action of thrombin. Synthetic PAF significantly induced secretion of ET, but the PAF receptor antagonists, WEB2086 and E6123, failed to modulate thrombin-induced ET release.

These results indicate that thrombin acts on pleural rat mesothelial cells to release ET and PAF, which may play a role in the development of pleurisy.
\end{abstract}

Eur Respir J 2000; 15: 170-176.

\author{
Second Dept of Internal Medicine, \\ Saitama Medical School, Moroyamacho, \\ Irumagun, Saitama, Japan. \\ Correspondence: Y. Sakamoto \\ Second Dept of Internal Medicine \\ Saitama Medical School \\ 38 Morohongo \\ Moroyamacho \\ Irumagun \\ Saitama 350-0495 \\ Japan \\ Fax: 81492958399
}

Keywords: Endothelins

mesothelial cells

platelet-activating factor

thrombin

Received: August 121998

Accepted after revision September 301999
Various kinds of disease affect the pleura, of which pleuritis is the most common. Most causes of pleuritis are infections, immunological and/or allergic diseases, and malignant neoplasms. Pleuritis is usually associated with exudative effusion; however, its exact mechanism has not been fully clarified yet. It has been recognized that not only inflammatory cells but also cells constituting the tissues are essential for inflammation. In this context, it has been reported that vascular endothelial cells produce cytokines, such as interleukin (IL)-6 and granulocyte-macrophage colony-stimulating factor as well as platelet-derived growth factor (PDGF), and also express class II antigen and adhesion molecules $[1,2]$. Therefore, it would be reasonable to speculate that mesothelial cells (MTCs) lining the surfaces of the lung and chest wall also act as effector cells in inflammatory or immunological responses, producing and releasing mediators or cytokines. Indeed, human MTCs can express IL-1 $\beta$, granulocyte colony-stimulating factor [3] and insulin-like growth factor-I [4] messenger ribonucleic acid, produce IL-6, IL-8 and monocyte chemotactic protein-1 upon stimulation with IL-1 or tumour necrosis factor- $\alpha[5]$, and express adhesion molecules [6]. It has also been reported that rat MTCs (RMTCs) synthesize fibroblast chemoattractant [7] and nitric oxide [8]. These findings support the hypothesis that pleural MTCs possess the ability to function as effector cells.

Embryologically, both pleural MTCs and vascular endothelial cells are epithelial cells derived from the mesoderm [9]. Endothelial cells produce lipid mediators such as prostaglandin $\mathrm{I}_{2}$ and platelet-activating factor (PAF) in response to various stimulants including thrombin [10]. PAF is a potent lipid mediator, which activates platelets, neutrophils, eosinophils and macrophages, and increases vascular permeability, leading to oedema formation [11]. Endothelin (ET) was originally identified as a 21-residue potent vasoconstrictor peptide in vascular endothelial cells. ET consists of at least three isoforms, ET-1, ET-2 and ET3 , revealed by genomic deoxyribonucleic acid (DNA) analysis [12]. Although many studies have been performed mainly focusing on ET-1, it has been revealed that these ET family peptides effect diverse biological actions in a paracrine or autocrine manner in both vascular and nonvascular tissues. One of those actions is its mitogenic effect on smooth muscle cells, myocytes and fibroblasts [13]. Moreover, ET acts in synergism with various growth factors including PDGF [13].

If PAF and ET are released by MTCs during inflammatory processes, PAF will probably augment the inflammation by activating leukocytes and increasing vascular permeability, and ET by enhancing fibrosis in the pleural cavity. Thrombin is a serine protease formed by the proteolytic cleavage of a proenzyme, prothrombin. Thrombin can be generated in various inflammatory processes. The biological action of thrombin is not restricted to haemostasis [14]. Indeed, thrombin induces the proliferation and chemotaxis of many types of cell including RMTCs [15]. Thrombin acts on endothelial cells to produce and release PAF, ET-1, etc. via thrombin receptors [16]. Therefore, if 
it is hypothesized that similarities between MTCs and endothelial cells exist, MTCs may possess thrombin receptors and be activated via such receptors. Therefore, the present study was designed to assess whether pleural RMTCs release PAF and ET upon stimulation with thrombin.

\section{Materials and methods}

\section{Reagents}

The specific PAF receptor antagonists, WEB2086 (molecular formula; $\left.\mathrm{C}_{23} \mathrm{H}_{22} \mathrm{ClN}_{5} \mathrm{O}_{2} \mathrm{~S}\right)$ and $\mathrm{E} 6123\left(\mathrm{C}_{23} \mathrm{H}_{22} \mathrm{Cl}\right.$ $\mathrm{N}_{5} \mathrm{OS}$ ), were provided by Boehringer Ingelheim (Ingelheim, Germany) and Eisai (Tokyo, Japan), respectively. Bovine thrombin, bovine antithrombin III (AT III), sphingomyelin, 1- $\alpha$-lysophosphatidylcholine, calcium ionophore A23187, indomethacin, lipopolysaccharide (LPS) (Escherichia coli 0111:B4) and bovine serum albumin (BSA) (fatty acid-free) were purchased from Sigma (St Louis, MO, USA), heparin, derived from porcine intestinal mucosa, from Leo Pharmaceutical Products (Ballerup, Denmark), thrombin receptor-activating peptide (TRAP; Ser-Phe-LeuLeu-Arg-Asn) from Peninsula Laboratories (St Helens, Merseyside, UK), 1-o-alkyl-2-o-acetyl-sn-glycero-3-phosphocholine (C16:0 PAF) from Bachem (Torrance, CA, USA), 1-o-[3H]-alkyl mixture of C16:0 and C18:0 PAF from Amersham (Amersham, UK), and synthetic ET-1, -2 and -3 from Peptide Institute (Osaka, Japan), respectively. Silica gel thin-layer chromatography (TLC) plates were purchased from Merck (Darmstadt, Germany).

\section{Culture}

RMTCs, line 4/4 R.M.-4, were purchased from the American Type Culture Collection and cultured successively in F-12K medium supplemented with $15 \%$ foetal calf serum (FCS), penicillin $\left(100 \mathrm{U} \cdot \mathrm{mL}^{-1}\right)$, streptomycin $\left(100 \mu \mathrm{g} \cdot \mathrm{mL}^{-1}\right)$ and glutamine $(2 \mathrm{mM})$ (complete medium) in an incubator with a $5 \% \mathrm{CO}_{2}$ atmosphere at $37^{\circ} \mathrm{C}$. The light microscopic view of these cells showed a flat cobblestone appearance. In subsequent experiments, cells between the 5th and 10th passage were used. When confluent cells were obtained in a culture flask, the cell layer was removed with $0.25 \%$ trypsin, washed three times, resuspended in complete medium, seeded into $35-\mathrm{mm}$ collagencoated tissue culture dishes (Sumitomo Bakelite, Osaka, Japan) and incubated until confluent. When confluent, there were $16.8 \pm 0.8 \times 105$ cells $\cdot$ dish $^{-1}$.

\section{Release of endothelin and platelet-activating factor}

In order to determine the amount of ET released, the culture medium was replaced with $1 \mathrm{~mL}$ of medium without FCS $4 \mathrm{~h}$ prior to stimulation. The cells were then incubated for 4 or $12 \mathrm{~h}$ at $37^{\circ} \mathrm{C}$. The supernatants were recovered and stored at $-80^{\circ} \mathrm{C}$ until assay. To determine the amount of PAF released, the culture medium was replaced with $1 \mathrm{~mL}$ of Hank's balanced salt solution (HBSS) containing $0.25 \%$ fatty acid-free BSA, $1.3 \mathrm{mM} \mathrm{CaCl}_{2}, 0.8 \mathrm{mM}$ $\mathrm{MgSO}_{4}$ (HBSS-BSA) $4 \mathrm{~h}$ prior to stimulation. An agonist was then added and incubated with the cells for up to 15 min at $37^{\circ} \mathrm{C}$. At each time point, the supernatants were transferred to polypropylene tubes (Sarstedt, Nümbrecht, Germany), and, after the immediate addition of $1 \mathrm{~mL} 50$ $\mathrm{mM}$ acetic acid in methanol to the monolayer to halt the reaction, cells were detached using a scraper (Costar, Cambridge, MA, USA) [17]. Total lipids were immediately extracted from the supernatants and cells according to the method of BLIGH and Dyer [18].

In some experiments, thrombin was preincubated with AT III, or with AT III and heparin, for $30 \mathrm{~min}$ to examine antagonistic effects on thrombin. A23187 was dissolved in dimethyl sulphoxide at a concentration of $5 \times 10^{-3} \mathrm{M}$.

\section{Immunoreactive endothelin assay}

Immunoreactive ET was assayed according to the method described previously [19]. Supernatant mixed with three volumes of $4 \%$ acetic acid was applied to a Sep-Pak $\mathrm{C}_{18}$ column (Waters, Milford, MA, USA) pretreated with ethanol containing 4\% acetic acid, methanol, distilled water and then $4 \%$ acetic acid. After washing with $4 \%$ acetic acid and distilled water, the ET-rich fraction was eluted with ethanol containing $4 \%$ acetic acid according to the method described by RosmaLen et al. [20]. This fraction was evaporated under nitrogen, dissolved in 1 $\mathrm{mL}$ ethanol and then evaporated again. The residue was dissolved in $50 \mathrm{mM}$ Good's buffer, $\mathrm{pH} 8.0$, and then sonicated for $10 \mathrm{~min}$ at $37^{\circ} \mathrm{C}$. After centrifugation for 5 $\min$ at $10,000 \times g$, the supernatant was retained. The amounts of ET in the supernatants were measured using an ET-1 enzyme-linked immunosorbent assay (ELISA) kit (Wako, Tokyo, Japan) and an ET-3 ELISA kit (IBL, Gunma, Japan). According to the manufacturers' information, the monoclonal antibodies against ET-1 employed in the ET-1 ELISA kit showed $\sim 160 \%$ cross-reactivity with ET-2 but not with other ET-related peptides, and the monoclonal antibodies against ET-3 were specific for ET3 alone.

Identification of endothelin isoforms by means of reversephase high-performance liquid chromatography

Subconfluent RMTCs were cultured for $48 \mathrm{~h}$ in F-12K medium supplemented with $15 \%$ FCS to enhance ET production. Culture supernatants $(50 \mathrm{~mL})$ were pooled, concentrated using a Sep-Pak $\mathrm{C}_{18}$ column, dried under nitrogen, then resuspended in 5\% acetonitrile containing $0.05 \%$ trifluoroacetic acid and then centrifuged for $5 \mathrm{~min}$ at $15,000 \times g$. The supernatants were loaded onto a TSK ODS-80 column (Tosho, Tokyo, Japan) and separated according to the method described previously [19]. The concentration of acetonitrile was increased linearly from $5-20 \%$ over $5 \mathrm{~min}, 20-39 \%$ over $20 \mathrm{~min}$, and then 39 $60 \%$ over $5 \mathrm{~min}$ at a flow rate of $1 \mathrm{~mL} \cdot \mathrm{min}^{-1}$. The retention time of the column was calibrated using synthetic ET-1, ET-2 and ET-3. During the $20-60 \%$ gradient $30-\mathrm{s}$ fractions were collected, evaporated and then assayed. The peaks of immunoreactive ET-1, ET-2 and ET-3 corresponded to those of synthetic ET-1, ET-2 and ET-3. The amounts of ET-1 and ET-2 in corresponding fractions were measured separately using the ET-1 assay kit using synthetic ET-1 and ET-2 as standards. The amount of ET3 was measured using an ET-3 ELISA kit. 


\section{Platelet-activating factor assay}

PAF was assayed according to the method described previously [21]. The chloroform layer containing lipids was dried under nitrogen, the residue dissolved in $100 \mu \mathrm{L}$ chloroform/methanol $(4: 1$, volume in volume $(\mathrm{v} / \mathrm{v}))$, spotted on to the TLC plate and then developed using chloroform $/ \mathrm{methanol} /$ water $(65: 35: 6, \mathrm{v} / \mathrm{v})$ as a solvent system. Sphingomyelin and 1- $\alpha$-lysophosphatidylcholine were applied to the TLC plate simultaneously and identified by their fluorescence under ultraviolet light after spraying with $0.01 \%$ primulin. The portion of gel corresponding to the sample and lying between these two markers was scraped and dissolved in chloroform/methanol/water (1:1: $0.8, \mathrm{v} / \mathrm{v})$, vigorously agitated on a vortex mixer, stirred and then centrifuged. The chloroform layer was dried under nitrogen. PAF was quantified by measuring its ability to aggregate washed rabbit platelets in an aggregometer (Hematracer 2; Nikko, Tokyo, Japan) according to the method of ODA et al. [22] with a slight modification. Platelet-rich plasma was prepared from blood drawn from a vein using acid/citrate/dextrose as an anticoagulant and washed twice with Tyrode's buffer containing $0.25 \%$ gelatin and $1 \mathrm{mM}$ ethylenediamine tetraacetic acid. Washed platelets were resuspended in Tyrode's buffer containing $0.5 \mathrm{mM} \mathrm{MgSO}_{4}, 1.8 \mathrm{mM} \mathrm{CaCl}_{2}$ and $0.25 \%$ gelatin at a density of $1 \times 10^{9}$ cells $\cdot \mathrm{mL}^{-1}$, and aliquots of $200 \mu \mathrm{L}$ were added to aggregometer cuvettes. Each sample or the standard (serially diluted synthetic PAF (C16:0)) dissolved in 0.25\% BSA/saline $(20 \mu \mathrm{L})$ was added to the platelet suspension, and the increase in light transmission depicted on a recorder.

\section{Identification of platelet-activating factor by high- performance liquid chromatography}

The following two experiments were performed in order to determine whether the separated lipid residue was PAF. 1) The residue was dissolved in $50 \mu \mathrm{L}$ isopropanol/hexane $(2: 1, v / v)$ and fractionated by means of high-performance liquid chromatography (HPLC) using a silica column ( $\mu$ Bondasphere; Waters; $5 \mu \mathrm{m}, 3.9 \times 150 \mathrm{~mm}$ ) as the stationary phase and isopropanol/hexane/water (110:100:20, $\mathrm{v} / \mathrm{v}$; flow rate $0.4 \mathrm{~mL} \cdot \mathrm{min}^{-1}$ ) as the mobile phase [23]. The retention time of the column for PAF was calibrated using ${ }^{3} \mathrm{H}$-labelled synthetic C16:0 and C18:0 PAF. Thirtysecond fractions were collected, and both the plateletaggregating activity and radioactivity of each fraction determined for comparative purposes. 2) PAF receptor antagonist, WEB2086 or E6123, was added to washed rabbit platelet suspension and preincubated for $2 \mathrm{~min}$ for the evaluation of its inhibitory effect. According to the manufacturers' instructions, WEB2086 was suspended in distilled water and dissolved at $30^{\circ} \mathrm{C}$ in an ultrasonic bath at a concentration of $10^{-2} \mathrm{M}$, and E6123 was dissolved in ethanol at a concentration of $10^{-2} \mathrm{M}$. These compounds were further diluted with distilled water and immediately used in experiments.

\section{Effects of platelet-activating factor on endothelin release}

In order to determine the effect of exogenously added PAF on ET release, synthetic C16:0 PAF was serially diluted $\left(10^{-3}-10^{-11} \mathrm{M}\right)$ in chloroform/methanol $(1: 1, \mathrm{v} / \mathrm{v})$. Each PAF solution was dried and dissolved in a 100-fold greater volume of F-12K medium containing $0.25 \%$ BSA at a final concentration of $10^{-5}-10^{-13} \mathrm{M}$ with vigorous agitation on a vortex mixer. The cell culture medium was then replaced by the medium containing PAF, and the cells incubated for $4 \mathrm{~h}$ at $37^{\circ} \mathrm{C}$. The same volume of chloroform/ methanol without PAF was used as control. To evaluate the effect of endogenously released PAF on thrombin-induced production of ET, WEB2086 $\left(10^{-6} \mathrm{M}\right)$ or E6123 $\left(10^{-7} \mathrm{M}\right)$, were added $10 \mathrm{~min}$ prior to the stimulation with thrombin and the cells incubated for $4 \mathrm{~h}$ at $37^{\circ} \mathrm{C}$.

\section{Statistical analysis}

Data were expressed as mean \pm SEM. Differences in the time-course of ET synthesis were compared using two-way analysis of variance (ANOVA) for repeated measures. Differences in the dose-dependency of ET release and the effects of TRAP, exogenous PAF and PAF receptor antagonists on ET release, and of AT III and heparin on ET and PAF release were analysed using one-way ANOVA. Any difference detected was evaluated by means of a post hoc test (Bonferroni). A p-value $<0.05$ was considered statistically significant.

\section{Results}

\section{Identification of endothelin isoforms}

The analysis by reverse-phase HPLC revealed that RMTCs release all three ET isoforms (fig. 1). The amounts of ET-1, ET-2 and ET-3 released were 3.96 (46\%), 3.26 $(38 \%)$ and $1.34 \mathrm{ng}(16 \%)$, respectively. Thus, the major ET constituents were ET-1 and ET-2. The combination ET-1 and ET-2 was, therefore, assayed using the ET-1 ELISA with synthetic ET-1 as the standard, and was designated arbitrarily as immunoreactive ET.

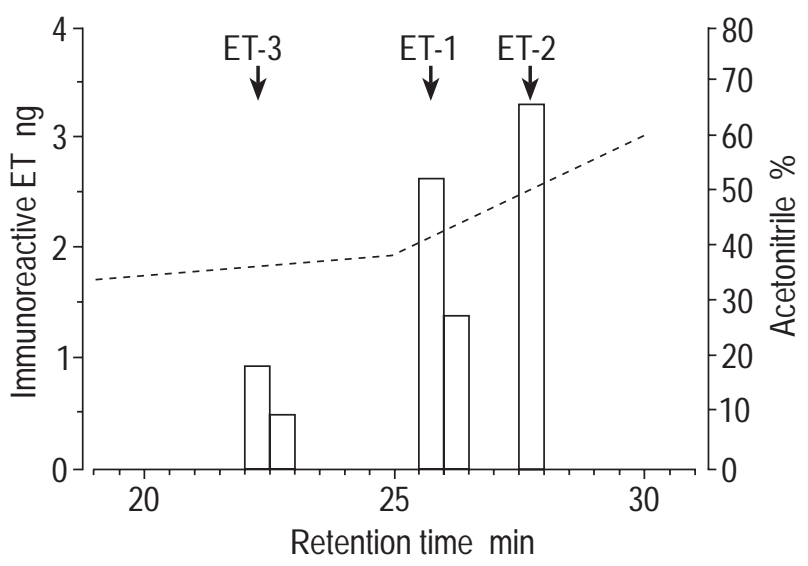

Fig. 1. - Reverse-phase high-performance liquid chromatography of rat pleural mesothelial cell (RMTC) culture supernatants. The pooled concentrated supernatants were fractionated using a TSK ODS-80 column. The amounts of endothelin (ET)-1, ET-2 and ET-3 in each fraction (30 s) were measured by means of enzyme-linked immunosorbent assay ( $\square$ ). The arrows indicate the peak elution fractions of synthetic ET-1, ET-2 and ET-3. - - - : acetonitrile concentration gradient. 


\section{Thrombin-induced release of immunoreactive ET}

RMTCs were incubated in the presence or absence of thrombin $\left(3 \mathrm{U} \cdot \mathrm{mL}^{-1}\right)$ for up to $12 \mathrm{~h}$. The release of immunoreactive ET was significantly enhanced by thrombin at both 4 and $12 \mathrm{~h}(\mathrm{p}<0.0001)$. The amounts of immunoreactive ET released from RMTCs by thrombin were $249 \pm 21 \mathrm{pg}$ at $4 \mathrm{~h}$ and $392 \pm 14 \mathrm{pg}$ at $12 \mathrm{~h}$, whereas those released spontaneously were $55 \pm 2 \mathrm{pg}$ at $4 \mathrm{~h}$ and $121 \pm 15 \mathrm{pg}$ at $12 \mathrm{~h}$, respectively (fig. $2 \mathrm{a}$ ). When incubated for $12 \mathrm{~h}$, the amounts of immunoreactive ET released by $0,1,3$ and $10 \mathrm{U} \cdot \mathrm{mL}^{-1}$ thrombin were $111 \pm 14,244 \pm 28,343 \pm 47$ and $406 \pm 17 \mathrm{pg}$, respectively. The amount of immunoreactive ET increased significantly in a thrombin concentrationdependent manner (fig. 2b). Statistically significant differences occurred between $1 \mathrm{U} \cdot \mathrm{mL}^{-1}$ and $3(\mathrm{p}<0.05)$ and $10 \mathrm{U} \cdot \mathrm{mL}^{-1}(\mathrm{p}<0.005)$, but not between $3 \mathrm{U} \cdot \mathrm{mL}^{-1}$ and 10 $\mathrm{U} \cdot \mathrm{mL}^{-1}$ thrombin. TRAP $(100 \mu \mathrm{M})$ also induced the release of immunoreactive ET (fig. 3). Calcium ionophore A23187 $\left(1 \times 10^{-7}-5 \times 10^{-6} \mathrm{M}\right)$ or LPS $\left(0.01-10 \mu \mathrm{g} \cdot \mathrm{mL}^{-1}\right)$ did not elicit any ET release at 4 or $12 \mathrm{~h}$ (data not shown).

\section{Identification and characterization of platelet-activating factor}

RMTCs were stimulated with A23187 at a final concentration of $5 \times 10^{-6} \mathrm{M}$ for $5 \mathrm{~min}$. The residue obtained from the supernatant induced irreversible aggregation of rabbit platelets, which was completely abrogated by preincubation of the platelets with WEB2086 $\left(10^{-6} \mathrm{M}\right)$ or E6123 $\left(10^{-7} \mathrm{M}\right)$ and was not affected by the presence of indomethacin $\left(3 \times 10^{-6} \mathrm{M}\right)$ in the platelet suspension (data not shown). Two separated peaks of platelet-aggregating activity were demonstrated by means of HPLC (fig. 4). The retention times were 17 and $19 \mathrm{~min}$, respectively. The second peak was more potent than the first in platelet aggregation, and showed the same elution position as ${ }^{3} \mathrm{H}-$ C16:0 PAF. The retention time of the first peak was between those of C16:0 and C18:0 PAF. This result indicated that RMTCs release mainly 16:0 PAF.
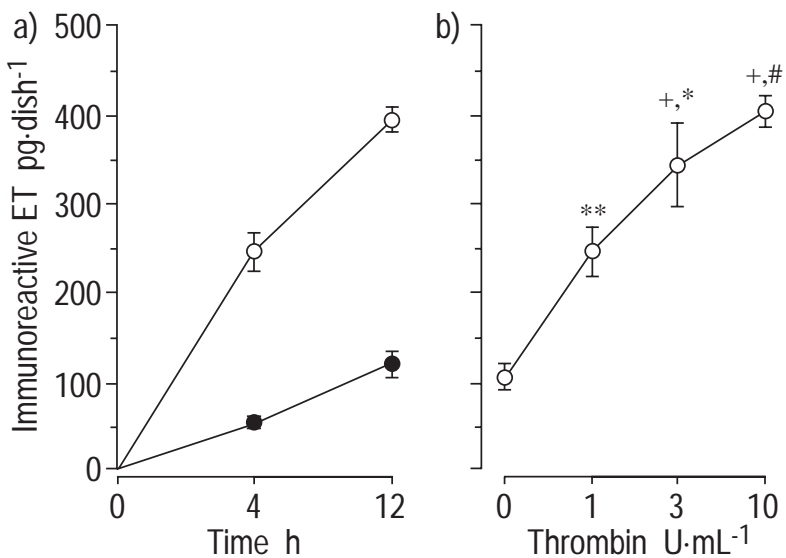

Fig. 2. - Thrombin-induced release of immunoreactive endothelin (ET). a) Time-course of thrombin-induced release of immunoreactive ET. Rat pleural mesothelia cells (RMTCs) were incubated in the presence $(O)$ or absence $(O)$ of thrombin $\left(3 \mathrm{U} \cdot \mathrm{mL}^{-1}\right)$ for 4 and $12 \mathrm{~h}$. Data are presented as mean $\pm \operatorname{SEM}(n=4)$. $+: \mathrm{p}<0.0001$. b) Concentration dependency of thrombin-induced immunoreactive ET release. RMTCs were incubated in the presence of various concentrations of thrombin for $12 \mathrm{~h}$. Data are presented as mean $\pm \operatorname{SEM}(\mathrm{n}=3) .{ }^{* *}: \mathrm{p}<0.01 ;{ }^{+}: \mathrm{p}<0.0001$ versus control; *: $\mathrm{p}<0.05 ;^{\#}: \mathrm{p}<0.005$ versus $1 \mathrm{U} \cdot \mathrm{mL}^{-1}$.

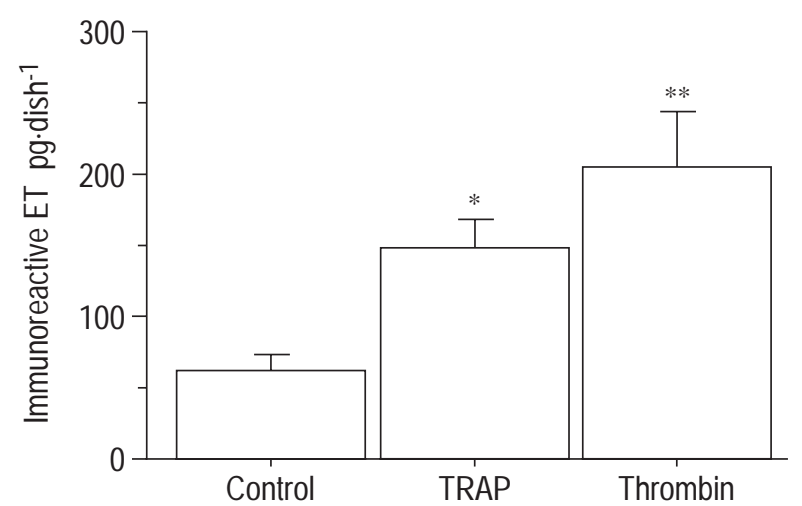

Fig. 3. - Effect of thrombin receptor-activating peptide (TRAP) on immunoreactive ET release. Rat pleural mesothelial cells were incubated in the presence of TRAP $(100 \mu \mathrm{M})$ or thrombin $\left(10 \mathrm{U} \cdot \mathrm{mL}^{-1}\right)$ for $4 \mathrm{~h}$. Data are presented as mean \pm SEM $(n=3)$. *: $\mathrm{p}<0.05 ;{ }^{* *}: \mathrm{p}<0.01$ versus control.

\section{Thrombin-induced release of platelet-activating factor}

The distribution of PAF was examined upon stimulation with thrombin $\left(3 \mathrm{U} \cdot \mathrm{mL}^{-1}\right)$. The amounts of cell-associated PAF at $0,5,10$ and $15 \mathrm{~min}$ after stimulation were $0,0.81$, 1.12 and $0.79 \mathrm{pmol}^{-} \mathrm{dish}^{-1}$, respectively, whereas the amounts of released PAF at the same time points were 0, 3.60, 2.96 and $0.17 \mathrm{pmol} \cdot \mathrm{dish}^{-1}$, respectively (fig. 5). This result indicated that most of the PAF generated was released extracellularly within $10 \mathrm{~min}$. The amounts of PAF released by 3 and $10 \mathrm{U} \cdot \mathrm{mL}^{-1}$ thrombin at $10 \mathrm{~min}$ were $3.57 \pm 1.11$ and $4.47 \pm 0.44 \mathrm{pmol} \cdot \mathrm{dish}^{-1}$, respectively $(\mathrm{n}=4)$, and no statistically significant difference occurred. The amount of PAF released by $5 \times 10^{-6} \mathrm{M} \mathrm{A23187}$ at $5 \mathrm{~min}$ was 23.17 $\pm 5.70 \mathrm{pmol} \cdot \mathrm{dish}^{-1}(\mathrm{n}=4)$, whereas LPS did not elicit PAF release (data not shown).

\section{Effects of antagonists on the release of immunoreactive} endothelin or platelet-activating factor

In order to examine the inhibitory effect of AT III, thrombin $\left(3 \mathrm{U} \cdot \mathrm{mL}^{-1}\right)$ was incubated with AT III $\left(0.3 \mathrm{U} \cdot \mathrm{mL}^{-1}\right)$

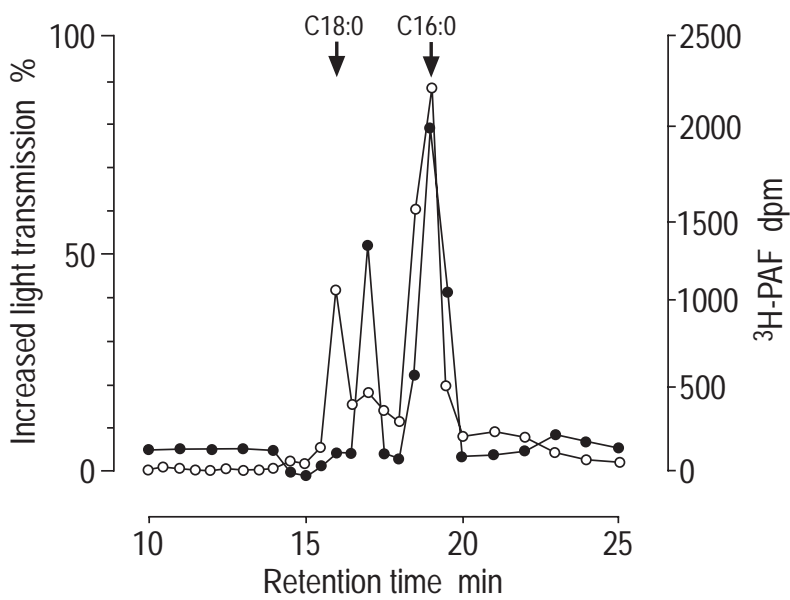

Fig. 4. - High-performance liquid chromatography of the culture supernatants of rat pleural mesothelial cells stimulated with A23187 $\left(5 \times 10^{-6}\right.$ M). After a 5-min stimulation, supernatants were collected and total lipids extracted immediately. The residue was fractionated using a silica column. $\bigcirc:{ }^{3} \mathrm{H}$-labelled synthetic platelet-activating factor (PAF); platelet-aggregating activity of the residue in each fraction. The arrows indicate the elution points of ${ }^{3} \mathrm{H}$-labelled C16:0 PAF and 18:0 PAF. dpm: disintegrations per minute. 


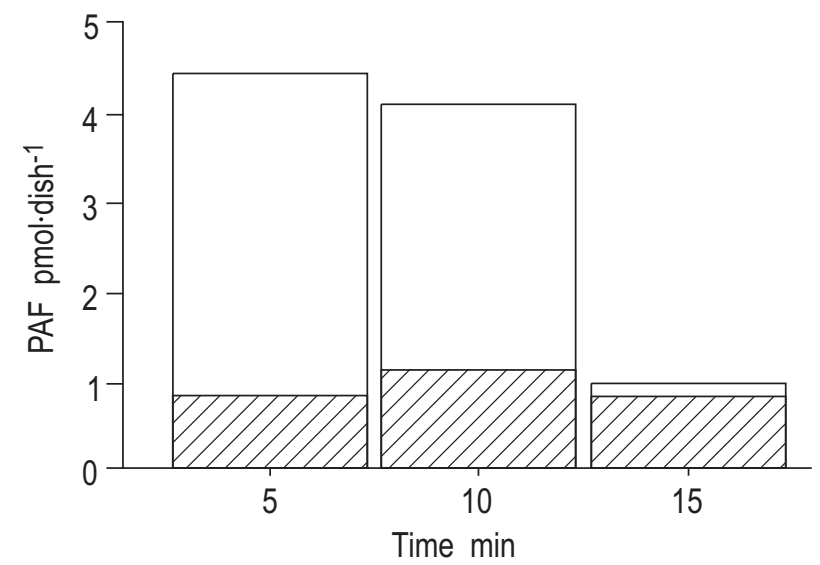

Fig. 5. - Distribution of platelet-activating factor (PAF) induced by thrombin. Rat pleural mesothelial cells were stimulated with thrombin (3 $\left.\mathrm{U} \cdot \mathrm{mL}^{-1}\right)$ and total lipids were extracted separately from the supernatants and from the cells at each indicated time. $\square$ : released PAF; $\mathbb{Z}$ : cellassociated PAF.

for $30 \mathrm{~min}$. To enhance the effect of AT III, $3 \mathrm{U} \cdot \mathrm{mL}^{-1}$, heparin was also added. RMTC monolayers in tissue culture dishes were incubated with the combination of thrombin, AT III and heparin for $12 \mathrm{~h}$ (for immunoreactive ET) or $10 \mathrm{~min}$ (for PAF). Since the PAF generated was mainly released extracellularly, the bioactivity of the PAF was assayed in the supernatants alone. AT III significantly inhibited the release of immunoreactive ET $(\mathrm{p}<0.01)$ and PAF $(p<0.05)$. The inhibitory effects of AT III were enhanced by heparin (immunoreactive ET, $\mathrm{p}<0.0001$; PAF, $\mathrm{p}<0.01$ ) (table 1).

\section{Effects of platelet-activating factor on immunoreactive endothelin release}

RMTCs were cultured in the presence of $10^{-5}-10^{-13} \mathrm{M}$ synthetic PAF for $4 \mathrm{~h}$. Immunoreactive ET was released significantly by stimulation with $10^{-7}$ and $10^{-5} \mathrm{M}$ PAF compared with control (fig. 6a). Next, to determine whether released PAF affects the release of immunoreactive ET, a PAF receptor antagonist, WEB2086 $\left(10^{-6} \mathrm{M}\right)$ or E6123 $\left(10^{-7} \mathrm{M}\right)$, was added $10 \mathrm{~min}$ prior to stimulation with thrombin $\left(3 \mathrm{U} \cdot \mathrm{mL}^{-1}\right)$ and the RMTCs incubated for 4 $\mathrm{h}$. The results showed that the presence of either WEB2086 or E6123 did not affect the thrombin-induced release of immunoreactive ET ( $p>0.5$ ) (fig. 6b).

Table 1. - Effects of antithrombin III (ATIII) and heparin on the synthesis of immunoreactive endothelin (ET) or platelet-activating factor (PAF)

\begin{tabular}{lcl}
\hline & $\begin{array}{c}\text { Immunoreactive ET } \\
\text { pg.dish }\end{array}$ & $\begin{array}{c}\text { Released PAF } \\
\text { pmol·dish }^{-1}\end{array}$ \\
\hline Control & $150 \pm 10$ & $0.59 \pm 0.22$ \\
Thrombin & $290 \pm 16$ & $4.46 \pm 1.58$ \\
Thrombin+ATIII & $220 \pm 10^{* *}$ & $1.25 \pm 0.49^{*}$ \\
Thrombin+ATIII+heparin & $157 \pm 8^{\#}$ & $0.40 \pm 0.40^{* *}$ \\
\hline
\end{tabular}

Data are presented as mean $\pm \operatorname{sem}(\mathrm{n}=5)$. Thrombin $\left(3 \mathrm{U} \cdot \mathrm{mL}^{-1}\right)$ was incubated with ATIII $\left(0.3 \mathrm{U} \cdot \mathrm{mL}^{-1}\right)$ or ATIII and heparin $(3$ $\mathrm{U} \cdot \mathrm{mL}^{-1}$ ) for 30 min. ${ }^{*}: \mathrm{p}<0.05 ;{ }^{* *}: \mathrm{p}<0.01{ }^{\#}: \mathrm{p}<0.001$ versus thrombin alone.
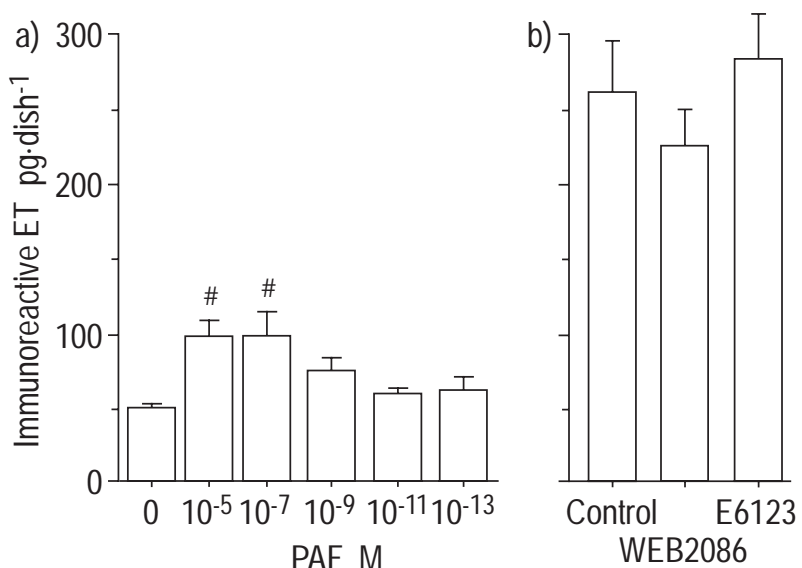

Fig. 6. - Effect of platelet-activating factor (PAF) on immunoreactive endothelin (ET) release. a) Rat pleural mesothelial cells (RMTCs) were incubated in the presence of various concentrations of synthetic PAF for $4 \mathrm{~h}$. Data are presented as mean $\pm \operatorname{SEM}(\mathrm{n}=5) .{ }^{\#}: \mathrm{p}<0.005$ versus control $(0$ M PAF). b) WEB2086 $\left(10^{-6} \mathrm{M}\right)$ or E6123 $\left(10^{-7} \mathrm{M}\right)$ were added $10 \mathrm{~min}$ prior to stimulation with thrombin and the RMTCs incubated for $4 \mathrm{~h}$. Data are presented as mean \pm SEM $(n=5)$.

\section{Discussion}

In vascular endothelial cells, ET is synthesized from prepro-ET, which is cleaved by an endopeptidase to form big ET. Big ET is then converted to ET by endothelinconverting enzyme. The ET family consists of at least three isoforms, ET-1, ET-2 and ET-3, due to differential splicing after transcription [12]. EID et al. [24] have shown the spontaneous and angiotensin II-induced release of ET-1 by epicardial RMTCs. KuWAHARA et al. [25] demonstrated that RMTCs released ET-1 via the action of FCS which may have contained thrombin. The present study confirms that RMTCs release all three isoforms, ET-1, ET-2 and ET-3. The percentages of ET-1:ET-2:ET-3 released were $\sim 46: 38: 16$, indicating that the predominant isoforms were ET-1 and ET-2. ET release was also inducible by thrombin in a concentration-dependent manner. Although ET was originally identified as a vasoconstrictor, one of its other actions is its mitogenic effect on smooth muscle cells, myocytes and fibroblasts [13]. Thus, ET-1 and ET-2 are equipotent in promoting DNA synthesis [13].

The involvement of PAF in pleurisy has been documented by some investigators. PAF-induced pleurisy in the rat accompanied by increases in the number of neutrophils and eosinophils in the exudate and zymosan-induced pleurisy were suppressed by PAF antagonists [26]. The fact that the platelet-aggregating activity of the substance released into the culture supernatant was not affected by the presence of indomethacin and completely inhibited by PAF-specific antagonists, and that the aggregating activity was eluted at a position corresponding to synthetic PAF on HPLC, indicated that this substance was PAF. The PAF generated was mainly released from RMTCs into the supernatants, and a smaller part remained cellassociated. Among several molecular species, C16:0, C18:0 and $\mathrm{C} 18: 1$ are known to have potent biological activities [27]. Furthermore, the molecular species are known to differ among animal species [28]. Upon HPLC identification, it was demonstrated that RMTCs release 
mainly C16:0 PAF. In addition, there was another platelet-aggregating activity, which eluted between $\mathrm{C} 18: 0$ and C16:0. Although it seemed to correspond to $C 17: 0$ or C18:1, speculating on the basis of a report on the reversephase HPLC analysis of various PAF species [28], the precise molecular species has not been identified yet.

PAF induced ET release when added exogenously. The PAF receptor antagonists, WEB2086 and E6123, were used to investigate the significance of PAF release from RMTCs in thrombin-induced ET release. Both are potent PAF antagonists, and the concentrations used have been shown to be adequate for the suppression of PAF-induced biological actions, including platelet aggregation. The results showed that neither antagonist significantly affected thrombin-induced ET release. The discrepancy between the effects of exogenously added PAF and endogenously released PAF could be explained by differences in concentrations. The concentration of PAF which significantly induced ET release was $>10^{-9} \mathrm{M}$, and the concentration of PAF released upon stimulation with thrombin was $\sim 10^{-9} \mathrm{M}$. Thus, it was speculated that thrombin stimulates RMTCs to release PAF, and that the released PAF may stimulate RMTCs to release ET through the PAF receptor, independent of the direct pathway of thrombin. Nevertheless, since the amount of PAF released was too small to induce significant ET release, the inhibitory effects of PAF receptor antagonists were obscure and failed to reach statistical significance in discriminating the direct effect of thrombin from the overall effect of thrombin, including the PAF-mediated pathway.

The present study demonstrated that thrombin stimulates RMTCs to release ET and PAF. Thrombin is a multifunctional serine protease [14]. Besides its classical role in blood coagulation, thrombin shows a variety of biological actions on platelets, endothelial cells, smooth muscle cells, etc., which possess the receptor for thrombin on their surface. Complementary DNA encoding a functional human thrombin receptor has been isolated, and it was revealed that the receptor is a member of the $G$ protein-coupled seven transmembrane domain receptor family [16]; many of the cellular effects of thrombin appear to be mediated via this receptor. It is a member of the protease-activated receptor family [29], and cellular activation by thrombin was shown to involve receptor proteolysis at an extracellular arginine residue; the newly generated amino terminus functions as a tethered ligand, which accomplishes receptor activation [16]. A synthetic peptide mimicking such a new amino terminus can activate the receptor independent of receptor cleavage, and was designated "thrombin receptor-activating peptide" (TRAP) [1]. The N-terminal hexapeptide sequence of the receptor following cleavage by thrombin is Ser-PheLeu-Leu-Arg-Asn in humans and Ser-Phe-Phe-Leu-ArgAsn in murines, and the substitution of phenylalanine for leucine is regarded as noncritical [30]. In this study, it was shown that TRAP induced the release of ET, indicating that 4/4 R.M.-4 rat mesothelial cells possess thrombin receptors.

Thrombin can be generated in a variety of inflammatory processes in the pleural cavity which is obvious from the common clinical finding that fibrin deposition occurs after exudative pleuritis. Unless fibrinous pleurisy is completely resolved, it is followed by adhesive pleurisy accompanied by pleural thickening. Thrombin, in exudates, converts fibrinogen to fibrin and causes the chemotaxis and proliferation of MTCs [15] and fibroblasts [14]. Since ET is a mitogen for fibroblasts and enhances the activity of PDGF [13], thrombin may play an important role in fibrogenesis accompanied by inflammation of the pleural cavity.

This study was performed to investigate the hypothesis that mesothelial cells share functional homology with vascular endothelial cells, since both of these cell types are epithelial cells derived from the mesoderm. This hypothesis might be incorrect; nonetheless, it would be of value to investigate other functional properties of mesothelial cells in comparison with the well-established functions of endothelial cells. This will contribute to the reconstitution of the inflammatory and immunological responses provoked in the pleural space. In conclusion, the present study demonstrates that 4/4 R.M.-4 rat pleural mesothelial cells release platelet-activating factor and endothelin upon stimulation with thrombin, and suggests that mesothelial cells may be involved in the inflammatory response in the pleural cavity, at least through the release of plateletactivating factor and endothelin. Since a mesothelial cell line was used as the cell source, it is mandatory that the results obtained are confirmed using primary cultures of mesothelial cells.

Acknowledgements. The authors thank A. Sakamoto and A. Yokote for technical assistance, K. Karasawa (Dept of Membrane Biology, Teikyo University), for helpful suggestions and technical support in platelet-activating factor analysis, and Y. Sakamoto and M. Nomura (First Dept of Physiology) for performing high-performance liquid chromatographic analysis.

\section{References}

1. Garcia JGN, Patterson C, Bahler C, Aschner J, Hart CM, English D. Thrombin receptor activation peptides induce $\mathrm{Ca} 2+$ mobilization, barrier dysfunction, prostaglandin synthesis, and platelet-derived growth factor mRNA expression in cultured endothelium. J Cell Physiol 1993; 156: $541-549$.

2. Kaplanski G, Marin V, Fabrigoule M, et al. Thrombinactivated human endothelial cells support monocyte adhesion in vitro following expression of intercellular adhesion molecule-1 (ICAM-1; CD54) and vascular cell adhesion molecule-1 (VCAM-1, CD106). Blood 1998; 92: 1259-1267.

3. Demetri GD, Zenzie BW, Rheinwald JG, Griffin JD. Expression of colony-stimulating factor genes by normal human mesothelial cells and human malignant mesothelioma cells lines in vitro. Blood 1989; 74: 940-946.

4. Lee TC, Zhang Y, Aston C, et al. Normal human mesothelial cells and mesothelioma cell lines express insulinlike growth factor I and associated molecules. Cancer Res 1993; 53: 2858-2864.

5. Antony VB, Hott JW, Kunkel SL, Godbey SW, Burdick MD, Strieter RM. Pleural mesothelial cell expression of $\mathrm{C}-\mathrm{C}$ (monocyte chemotactic peptide) and C-X-C (interleukin 8) chemokines. Am J Respir Cell Mol Biol 1995; 12: 581-588.

6. Jonjic N, Peri G, Bernasconi S, et al. Expression of adhesion molecules and chemotactic cytokines in cultured human mesothelial cells. J Exp Med 1992; 176: 11651174. 
7. Kuwahara M, Kuwahara $M$, Verrna $K$, Ando $T$, Hemenway DR, Kagan E. Asbestos exposure stimulates pleural mesothelial cells to secrete the fibroblast chemoattractant fibronectin. Am J Respir Cell Mol Biol 1994; 10: $167-176$.

8. Owens MW, Grisham MB. Nitric oxide synthesis by rat pleural mesothelial cells: induction by cytokines and lipopolysaccharide. Am J Physiol 1993; 265: L110-L116.

9. Langman J. Embryonic period (fourth to eighth week). In: Langman J, ed. Medical Embryology. Baltimore, Williams \& Wilkins, 1981; pp. 55-73.

10. Prescott SM, Zimmerman GA, McIntyre TM. Human endothelial cells in culture produce platelet-activating factor (1-alkyl-2-acetyl-sn-glycero-3-phosphocholine) when stimulated with thrombin. Proc Natl Acad Sci USA 1984; 81: 3534-3538.

11. Vargaftig BB, Pretolani M, Coëffier E, Chignard M. Platelet activating factor: biology, receptors and antagonists. In: Henson PM, Murphy RC, eds. Mediators of the Inflammatory Process. New York, Elsevier, 1989; pp. 113-146.

12. Inoue $\mathrm{A}$, Yanagisawa $\mathrm{M}$, Kimura $\mathrm{S}$, et al. The human endothelin family - 3 structurally and pharmacologically distinct peptides predicted by 3 separate genes. Proc Natl Acad Sci USA 1989; 86: 2863-2867.

13. Battistini B, Chailler P, D'Orleans-Juste P, Briere N, Sirois P. Growth regulatory properties of endothelins. Peptides 1993; 14: 385-399.

14. Bar-Shavit R, Benezra M, Sabbah V, Bode W, Vlodavsky I. Thrombin as a multifunctional protein: induction of cell adhesion and proliferation. Am J Respir Cell Mol Biol 1992; 6: 123-130.

15. Hott JW, Sparks JA, Godbey SW, Antony VB. Mesothelial cell response to pleural injury: thrombin-induced proliferation and chemotaxis of rat pleural mesothelial cells. Am J Respir Cell Mol Biol 1992; 6: 421-425.

16. Vu T-KH, Hung DT, Wheaton VI, Coughlin SR. Molecular cloning of a functional thrombin receptor reveals a novel proteolytic mechanism of receptor activation. Cell 1991; 64: 1057-1068.

17. McIntryre TM, Zimmerman GA, Satoh K, Prescott SM. Cultured endothelial cells synthesize both platelet-activating factor and prostacyclin in response to histamine, bradykinin, and adenosine triphosphate. $J$ Clin Invest 1985; 76: 271-280.

18. Bligh EG, Dyer WJ. A rapid method of total lipid extraction and purification. Can J Biochem Physiol 1959; 37: 911-917.

19. Kobayashi Y, Sakamoto Y, Shibasaki M, Kimura I, Matsuo H. Human alveolar macrophages synthesize endothelins by thrombin. J Immunol 1997; 158: 5442-5447.

20. Rosmalen FMA, Tan ACITL, Tan HS, Benraad TJ. A sensitive radioimmunoassay of atrial natriuretic peptide in human plasma, using a tracer with an immobilized glycouril agent. Clin Chim Acta 1987; 165: 331-340.

21. Yamamoto $\mathrm{H}$, Nagata $\mathrm{M}$, Tabe $\mathrm{K}$, et al. The evidence of platelet activation in bronchial asthma. J Allergy Clin Immunol 1993; 91: 79-87.

22. Oda M, Satouchi K, Yasunaga K, Saito K. Molecular species of platelet-activating factor generated by human neutrophils challenged with ionophore A23187. J Immunol 1985; 134: 1090-1093.

23. Hayashi M, Kimura J, Yamaki K, et al. Detection of platelet-activating factor in exudates of rats with phorbol myristate acetate-induced pleurisy. Thromb Res 1987; 48: 299-310.

24. Eid H, de Bold MLK, Chen JH, de Bold AJ. Epicardial mesothelial cells synthesize and release endothelin. $J$ Cardiovasc Pharmacol 1994; 24: 715-720.

25. Kuwahara M, Kuwahara M, Suzuki N. Production of endothelin-1 and big-endothelin- 1 by pleural mesothelial cells. FEBS Lett 1992; 298: 21-24.

26. Martins MA, Silva PMR, Faria Neto HC, et al. Pharmacological modulation of PAF-induced rat pleurisy and its role in inflammation by zymosan. Br J Pharmacol 1989; 96: 363-371.

27. Carolan EJ, Casale TB. Degree of platelet activating factor-induced neutrophil migration is dependent upon the molecular species. J Immunol 1990; 145: 2561-2565.

28. Mueller HW, O'Flaherty JT, Wykle RL. The molecular species distribution of platelet-activating factor synthesized by rabbit and human neutrophils. J Biol Chem 1984; 259: 14554-14559.

29. Kahn ML, Hammes SR, Botka C, Coughlin SR. Gene and locus structure and chromosomal localization of the protease-activated receptor gene family. $J$ Biol Chem 1998; 273: 23290-23296.

30. Vouret-Craviari V, Van Obberghhen-Schilling E, Rasmussen UB, Pavirani A, Lecocq J-P, Pouysségur J. Synthetic a-thrombin receptor peptides activate $G$ proteincoupled signaling pathways but are unable to induce mitogenesis. Mol Biol Cell 1992; 3: 95-102. 